\title{
MUTATIONS RATE IN DIFFERENT LINES OF DROSOPHILA MELANOGASTER AFTER THE TREATMENT WITH CAFFEINE AND HE-NE LASER RADIATION
}

\author{
O.V. Gorenskaya \\ Cand. Sci. (Biol.), Assoc. Prof. \\ Dep. Genetics and Cytology \\ V.N. Karazin Kharkiv National University \\ 4 Svobody Sq., Kharkiv, 61022, Ukraine \\ tel.: +38 (096) 971-83-99 \\ e-mail: olgavg2014@gmail.com \\ ORCID: 0000-0003-0028-2522
}

\author{
N.S. Filiponenko \\ Senior Assistant \\ Dep. Genetics and Cytology \\ V.N. Karazin Kharkiv National University \\ 4 Svobody Sq., Kharkiv, 61022, Ukraine \\ tel.: +38 (066) 611-07-03 \\ e-mail: filiponenkon@gmail.com \\ ORCID : 0000-0002-8116-9101
}

\section{Yu.G. Shckorbatov \\ Dr. Sci. (Biol.), Prof. \\ Dep. Molecular Biology and Biotechnology, \\ V.N. Karazin Kharkiv National University \\ 4 Svobody Sq., Kharkiv, 61022, Ukraine \\ tel.:+38 (050) 401-58-57 \\ e-mail: yuriy.shckorbatov@gmail.com \\ ORCID: 0000-0002-3315-0932}

The frequency of dominant lethal mutations (DLM) after combined effect of caffeine (1,3,7-trimethylxanthine) and helium-neon laser radiation in Drosophila has been studied. Caffeine is a natural substance which is presented in many drinks, widely applied in medicine and reveals moderately toxic action and some mutagenicity/genotoxicity effects; red laser radiation is applied in medicine and can disrupt the processes of DNA and RNA biosynthesis. The aim of this work was to study the characteristics of the mutation process in Drosophila melanogaster under the influence of caffeine and red laser radiation, depending on the genotype.

We used wild type Drosophila melanogaster stocks Canton-S $(C-S)$ and Oregon (Or), carrying an ebony mutation, respectively: ebonyc-s and ebonyor; and mutant stock ebony. Control flies were grown in standard conditions, and in experiments with caffeine it was added in culture medium in concentration $0.5 \mathrm{mg} / \mathrm{ml}$. Virgin flies were exposed to a helium-neon laser light (wavelength of 632,8 nm) with a surface power density of $0.03 \mathrm{~mW} / \mathrm{cm}^{2}$, the exposure time was 5 minutes.

The influence of caffeine causes an increase in the frequency of early DLM on $40 \%$ in mutant line ebony, and on $70.5 \%$ in the line ebonyc-s. Irradiation by light of helium-neon laser either reduces the incidence DLM, or has no effect in all lines used in this work. The simultaneous effect of two external factors induces diverse answers in different genotypes: it increases early DLM in line C-S and early and late DLM in line ebony; but has no effect in lines ebonyor and ebonyc-s. The two-way analysis ANOVA F-test showed that the DLM frequency dependence impact of external factors is characterized by $\mathrm{F}=3.87$; of genotype $\mathrm{F}=5.14$; of the combined effects of genotype and external factors $\mathrm{F}=5.69$. The power of influence of external factors $-8.1 \%$; of genotype $6.9 \%$; and of the combined effects of the genotype and two external factors studied $-31.4 \%$.

Conclusions. Irradiation with laser light had no mutagenic effect on Drosophila, and even revealed antimutagenic effect. Caffeine induced the DLM increase, but the combined caffeine and laser light impact increased DLM rate in line ebony and not influenced it in lines: ebonyor and ebonyc-s.

Key words: dominant lethal mutations; Drosophila development; mutagenic effect; antimutagenic effect.

\section{ОСОБЛИВОСТІ МУТАЦІЙНОГО ПРОЦЕСУ У РІЗНИХ ЛІНІЙ DROSOPHILA MELANOGASTER ЗА УМОВ СПІЛЬНӦ̈ ДІї КОФЕЇНУ І ВИПРОМІНЮВАННЯ НЕ-NЕ ЛАЗЕРУ}

О.В. Горенська, Н.С. Філіпоненко, Ю.Г. Шкорбатов

Харківський національний університет імені В.Н. Каразіна, м. Харків, Украӥна

Досліджено частоту домінантних летальних мутацій (ДЛМ) у дрозофіли після спільного впливу кофеїну (1,3,7-триметилксантин) і гелій-неонового лазеру. Метою даної роботи було вивчення особливостей мутаційного процесу у Drosophila melanogaster під впливом кофеїну і випромінювання гелій-неонового лазера в залежності від генотипу.

Експерименти проводили на лініях дикого типу Drosophila melanogaster Canton-S (CS) i Oregon $(\mathrm{Or})$, які несуть мутантний ген ebony, і мутантної лінії ebony. Лінії були взяті з колекції ліній дрозофіли 
кафедри генетики і цитології біологічного факультету Харківського національного університету імені В.Н. Каразіна. У контролі мух вирощували в стандартних умовах, у дослідах кофеїн додавали в середовище для культивування мух в концентрації 0,5 мг/мл. Віргіних мух піддавали впливу гелій-неонового лазерного випромінювання (632,8 нм) з щільністю потоку енергії 0,03 мВт/см² (тривалість впливу - 5 хвилин).

Результати роботи показали, що вплив кофеїну збільшує частоту ранніх ДЛМ на $40 \%$ у мутантної лінії ebony і на 70,5\% у лінії ebonyc-s. Опромінення світлом гелій-неонового лазеру призводить до зниження частоти ДЛМ. Одночасна дія зовнішніх чинників викликає різноспрямований ефект, залежний від генотипу досліджуваної лінії: збільшується частота ранніх ДЛМ у лінії $C-S$ і ранніх і пізніх ДЛМ у лінії ebony. У ліній ebonyor і ebonyc-s рівень ембріональної смертності не відрізняється від контрольних значень. Двохфакторний дисперсійний аналіз показав, що частота ДЛМ визначається зовнішнім впливом ( $\mathrm{F}=3,87)$; генотипом ( $\mathrm{F}=5,14)$ і поєднаною дієюзовнішніх і внутрішніх факторів $(\mathrm{F}=5,69)$. Сила впливу зовнішніх факторів - 8,1\%; генотипу 6,9\%; спільної дії зовнішніх і внутрішніх факторів - 31,4\%. Досліджена частота домінантних летальних мутацій у ліній дикого типу Canton-S, мутантної лінії ebony і ліній з заміщеним генотипом ebonyc-s та ebonyor при одночасній дії кофеїну (1,3,7-trimethylxanthine) i лазерного випромінювання. Показано, що сумарна частота виникаючих домінантних летальних мутацій залежить від усіх розглянутих у роботі факторів: від генотипу $\mathrm{F}=5,14$, від впливу досліджуваних зовнішніх факторів $\mathrm{F}=3,87$, і від поєднаної дії генотипу і зовнішніх факторів $\mathrm{F}=5,69$. В цьому випадку сила впливу генотипу склала 6,9\%, зовнішніх факторів - 8,1 \% і поєднаної дії обох досліджуваних факторів - 31,4\%.

Висновки. Опромінення лазерним випромінюванням не мало мутагенного ефекту на Drosophila, і навіть виявило антимутагенний ефект. Кофеїн викликав збільшення ДЛМ, але комбінований вплив кофеїну та лазерного випромінювання збільшив частоту ДЛМ у лінії ebony і не вплинув на частоту ДлМ в лініях ebonyor та ebonyc-s.

Ключові слова: домінантні летальні мутації; розвиток дрозофіли; мутагенний ефект; антимутагенний ефект.

\title{
ОСОБЕННОСТИ МУТАЦИОННОГО ПРОЦЕССА У РАЗЛИЧНЫХ ЛИНИЙ DROSOPHILA MELANOGASTER ПРИ КОМБИНИРОВАННОМ ДЕЙСТВИИ КОФЕИНА И ИЗЛУЧЕНИЯ НЕ-NЕ ЛАЗЕРА
}

\author{
О.В. Горенская, Н.С. Филипоненко, Ю.Г. Шкорбатов \\ Харьковский национальный университет имени В.Н. Каразина, г. Харьков, Украина
}

Исследована частота доминантных летальных мутаций (ДЛМ) у дрозофилы после совместного воздействия кофеина (1,3,7-триметилксантина) и гелий-неонового лазера. Целью данной работы было изучение особенностей мутационного процесса у Drosophila melanogaster под влиянием кофеина и излучения гелий-неонового лазера в зависимости от генотипа.

Эксперименты проводились на линиях дикого типа Drosophila melanogaster Canton-S $(C-S)$ и Oregon $(\mathrm{Or})$, несущих мутантный ген ebony, и мутантной линии еbony. Линии были взяты из коллекции линий дрозофил кафедры генетики и цитологии биологического факультета Харьковского национального университета имени В.Н. Каразина. В контроле мухи выращивали в стандартных условиях, в опытах кофеин добавляли в среду для культивирования мух в концентрации 0,5 мг/мл. Виргинные мухи подвергались воздействию гелий-неонового лазерного излучения (длина волны 632,8 нм) с плотностью потока энергии 0,03 мВт/ $\mathrm{cm}^{2}$ (время воздействия - 5 минут).

Результаты работы показали, что воздействие кофеина увеличивает частоту ранних ДЛМ на $40 \%$ у мутантной линии ebony и на 70,5\% у линии ebonyc-s. Облучение светом гелий-неонового лазера приводит к снижению частоты ДЛМ. Сочетанное действие внешних факторов вызывает разнонаправленный эффект, зависимый от генотипа исследуемой линии: увеличивается частота ранних ДЛМ у линии $C-S$ и ранних и поздних ДЛМ у линии ebony. У линий ebonyor и ebonyc-s уровень эмбриональной смертности не отличались от контрольных значений. Двухфакторный дисперсионный анализ показал, что частота ДЛМ определяется внешними воздействиями $(\mathrm{F}=3,87)$; генотипом $(\mathrm{F}=5,14)$ и сочетанием действия внешних и внутренних факторов $(\mathrm{F}=5,69)$. Сила влияния внешних факторов $-8,1 \%$; генотипа 6,9\%; совместного действия внешних и внутренних факторов $-31,4 \%$.

Выводы. Облучение лазерным светом не имело мутагенного эффекта на Drosophila, а также выявило антимутагенный эффект. Кофеин вызвал увеличение ДЛМ, комбинированное воздействие кофеина и лазерного излучения увеличило частоту ДЛМ в линии ebony и не повлияло на частоту ДлМ в линиях ebonyor и ebonyc-s.

Ключевые слова: доминантные летальные мутации; развитие дрозофилы; мутагенный эффект; антимутагенный эффект. 


\section{Introduction}

The studies of mutation rate in organisms in the process of their adaptation now become particularly relevant in relation to environmental issues. Caffeine is a natural substance which is presented in tea and coffee, is widely applied in medicine and reveals moderately toxic action and some mutagenicity/genotoxicity and carcinogenicity effects [1]. Radiation of helium-neon laser is applied in medicine and has many biological activities [2]. Among the basic model objects to study the mechanisms of influence on adaptive stress is Drosophila. The study of the mutation process of organisms in stressful conditions in relation to genotype is important for understanding the mechanisms of adaptation to adverse conditions and also in connection with differences in adaptive capacity of different genotypes.

Thus, the aim of this work was to study the characteristics of the mutation process in Drosophila melanogaster under the influence of caffeine and radiation of helium-neon laser, depending on the genotype.

\section{Materials and methods}

We used wild type Drosophila melanogaster lines Canton-S (C-S) and Oregon (Or), mutant line ebony, and also lines bearing ebony mutation which were obtained by saturating crosses of ebony line with lines $C-S$ on Or, respectively: ebonyc-s and ebonyor. All Drosophila lines were cultivated in standard culture vessels in sugar-yeast medium in an incubator at temperature of $23 \pm 0,5^{\circ} \mathrm{C}$. Sorting flies by sex was performed on the first day after flies leaving the puparium. In the experiment were taken only virgin flies. The diethyl ether was used for narcotizing flies.

Control flies were grown in standard conditions and in experiments with caffeine it was added in culture medium in concentration $0.5 \mathrm{mg} / \mathrm{ml}$. Virgin flies were exposed to a helium-neon laser red light (wavelength of $632.8 \mathrm{~nm}$ ) with a surface power density of $0.03 \mathrm{~mW} / \mathrm{cm}^{2}$, the exposure time was 5 minutes. The experiment was done in two variants - after the development of flies in the medium with caffeine and after the development of flies in standard conditions.

The frequency of dominant lethal mutations (DLM) was assessed by a percentage of eggs that are not developed of the total number of fertilized eggs. Dead eggs were classified in two groups: the transparent and light opaque eggs - as bearing the early lethal mutations (death of the embryo occurred in the period up to 6-9 h of embryonic development); dark eggs - as bearing late lethal mutations (the death of the embryo occurred later $9 \mathrm{~h}$ of embryonic development) [3].

The statistical analysis was done using the program Biostat 2009 (AnalystSoft, USA). Statistical significance of differences between mean values was determined by the two-sided Student's t-test (at $\mathrm{P}<0,05$ ). Statistical significance and the power of factors was assessed using two-factor analysis of variance (ANOVA) by the Snedecor's method.

\section{Results}

The results of the study of early and late dominant lethal mutations frequency in mutant lines and wildtype Drosophila lines depending on the combined effects of caffeine and laser irradiation treatment are shown in Figures 1-4.

The influence of caffeine causes an increase in the frequency of early DLM on $40 \%$ in mutant line ebony, and on $70.5 \%$ - in the line ebonyc-s (Fig. 2, 3).

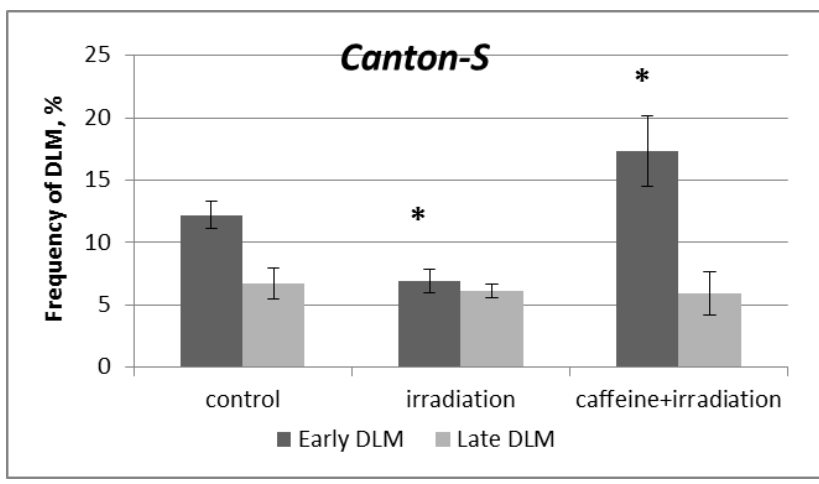

Fig. 1. Frequency of early and late DLM in wild type line Canton-S, depending on the action of caffeine and red laser light.

${ }^{*}$ Statistical significance of difference from control $\mathrm{P}<0.05$

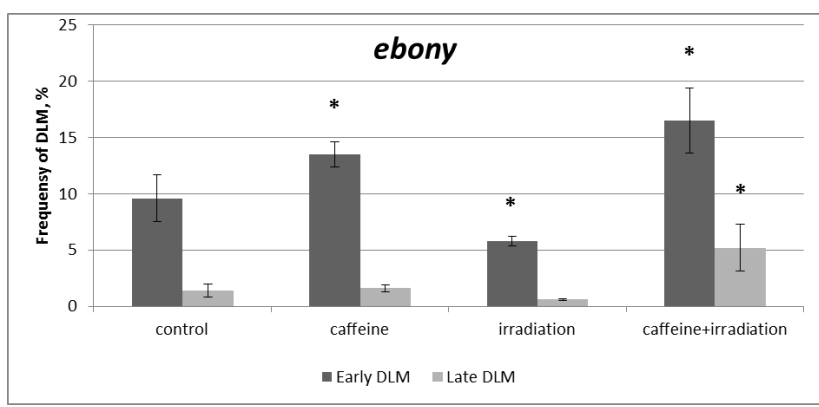

Fig. 2. Frequency of early and late DLM in line ebony after action of physical and chemical factors.

${ }^{*}$ Statistical significance of difference from control $\mathrm{P}<0.05$

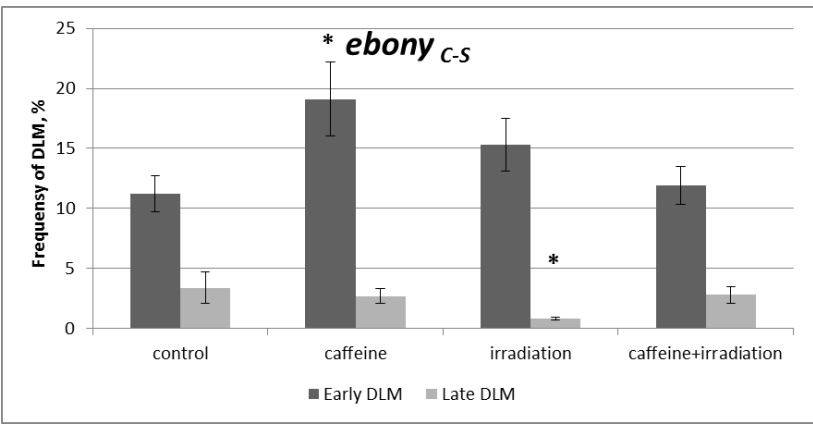

Fig. 3. Frequency of early and late DLM mutant line ebonyc-s after the action of physical and chemical factors. ${ }^{*}$ Statistical significance of difference from control $\mathrm{P}<0.05$ 


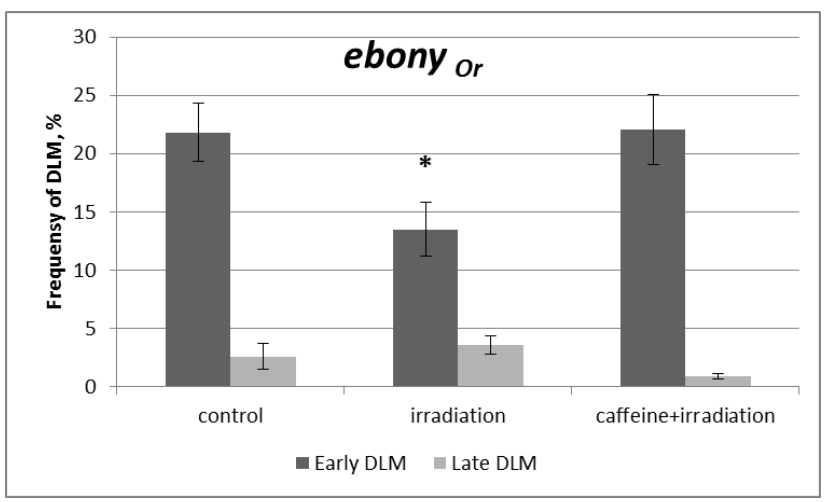

Fig. 4. Frequency of early and late DLM mutant lines ebonyor after action of physical and chemical factors. ${ }^{*}$ Statistical significance of difference from control $\mathrm{P}<0.05$

Irradiation by light of helium-neon laser either reduces the incidence DLM, or has no effect in all lines used in this work (Fig. 1-3). The simultaneous effect of two external factors induces diverse answers in different genotypes: it increases early DLM in line C-S and early late DLM in line ebony; but has no effect in lines ebonyor and ebonyc-s (Fig. 1-4).

The total incidence of DLM after the combined influence of caffeine and laser irradiation in Drosophila depended on the genotype as shown in Fig. 5.

The two-way analysis ANOVA F-test showed that the DLM frequency dependence impact of external factors is characterized by $\mathrm{F}=3.87$; of genotype $\mathrm{F}=5.14$; of the combined effects of genotype and external factors $\mathrm{F}=5.69$. The power of influence of external factors $-8.1 \%$; of genotype $6.9 \%$; and of the combined effects of the genotype and two external factors studied $-31.4 \%$.

\section{Discussion}

In the present work is was shown that the caffeine treatment of larvae is resulted with the increase of mutation incidence in Drosophila of lines ebony, ebonyc-s, and ebonyor (Fig. 2-5). This result is consistent with obtained previous results indicating an increase in the frequency of DLM under chronic caffeine exposure in Drosophila mutant lines [4]. The main mechanism of action of caffeine is associated with the regulation of intracellular cAMP (cyclic adenosine monophosphate) levels, which is directly related to the change of calcium level in the cell. In addition, the effect of caffeine leads to a change in the conformation of the DNA molecule by embedding instead of or between the bases [5]. Our results are in a good agreement with known effects, for instance, caffeine cause mutagenic effects [6], and by violation of DNA repair induce accelerated aging [7].

The experimental data show that the laser light exposure never increases the DLM incidence, but vise versa, decreases it (Fig. 1-5). This result corresponds to conclusion of A.Budagovsky that the low-intensity laser irradiation of visible spectrum is not a mutagenic factor and its application does not involve the risk of genetic modification of plants. The phenomenon that is regarded as a laser radiation mutagenesis is a result of the other processes, leading to the same consequences [8].

The ebony mutation is localized in chromosome 3 and causes darker body color in adults. Melanization in most organisms have an adaptive effect [9]. Thus, melanin, causing dark body color, involved in the formation of resistance in Drosophila by the action of different pathogens [10]. Melanins in animals are antioxidant pigments acting as free radical scavenging mechanisms [11]. But in our experiments the mutant line ebony not revealed more resistance to caffeine demonstrating that in this case the additional portion of melanin has no protective effect on caffeine-induced mutagenesis (Fig. 2, 3)
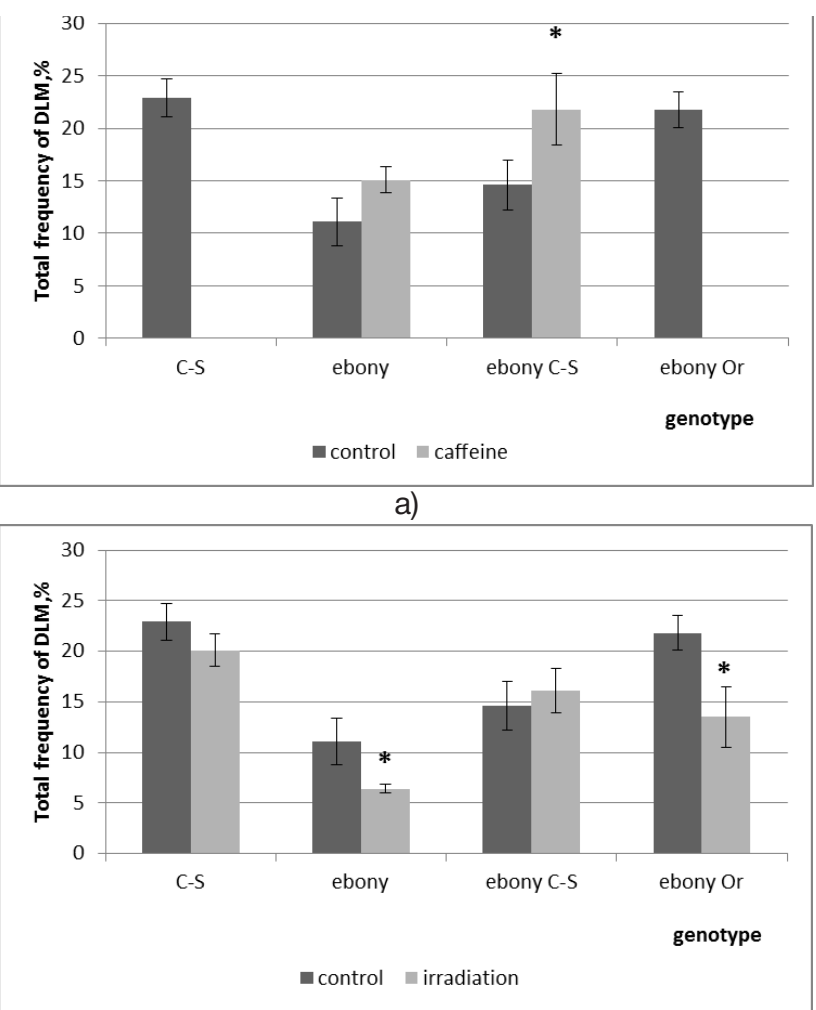

b)

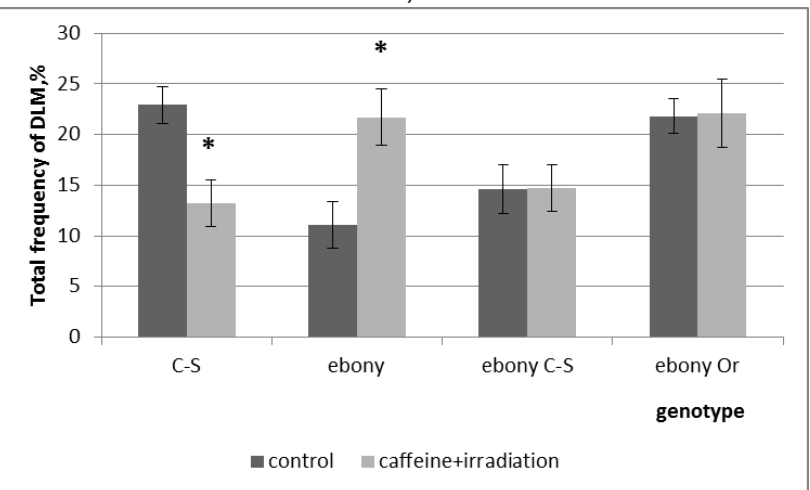

C)

Fig. 5. The total frequency of DLM, \% after the influence of caffeine (a), laser irradiation (b) and combined influence of caffeine and laser irradiation (c) in Drosophila depending on the genotype.

*Statistical significance of difference from control $P<0.05$ 
In our experiments the combined effects of caffeine and laser light induced increase in DLM rate only in the line of Drosophila ebony, but not in the line Canton-S. The DLM rate in mutant lines ebonyor and ebonyc-s not changed under the combined impact of caffeine and laser light. In our opinion this is connected with weakened "genetic background" of the line ebony.

\section{Conclusion}

Thus, the results show that laser light in our experiments had no mutagenic effect on Drosophila, and revealed antimutagenic effect. Caffeine induced the DLM increase. The incidence of dominant lethal mutations under combined caffeine and laser light impact increased in line ebony but was not influenced in the lines with mutant genotype saturated with genotypes of wild-type lines: ebonyor and ebonyc-s. ANOVA test revealed that the most impact on mutation rate variability had the effects connected with interaction of genotype and external factors - caffeine and laser light exposure.

\section{References}

1. Nawrot P, Jordan S, Eastwood J, Rotstein J, Hugenholtz A, Feeley M. Effects of caffeine on human health. Food Addit Contam. 2003 Jan;20(1):1-30.
2. Farivar S, Malekshahabi T, Shiari R. Biological effects of low level laser therapy. J Lasers Med Sci. 2014;5(2):58-62.

3. Tikhomirova MM. Geneticheskiy analiz: uchebnik [Genetic analysis: Textbook]. Leningrad: Leningrad State University Publ.; 1990. 280 p. (in Russian).

4. Horenskaya OV. Formation of adaptivity to caffeine exposure in Drosophila melanogaster. Bulletin of Kharkiv Karazin National University. Series: biology. 2010; 10(905): 66-77.

5. Deriabina AS, Grokhlina TI, Polteva NA et al. Study of Mechanisms of Some Caffeine Biological Effects via Computer. Simulation of Its Interactions with DNA Fragments. J. Mol. Struct. (Theochem). 2006;769(1-3);97-101.

6. Clark AM, Clark EG. The genetic effects of caffeine in Drosophila melanogaster. Mutation Research.1968; 6:227-34.

7. Nikitin AG, Navitskas S, Gordon LN. Effect of varying doses of caffeine on life span of Drosophila melanogaster. J Gerontol: Biol Sci. 2008;63A(2):149-50.

8. Budagovsky A. Does the low-intensity laser radiation have mutagenic effect? Photonics. 2013;38(2):114-27.

9. Cook LM, Turner JRG. Decline of melanism in two British moths: spatial, temporal and inter-specific variation. Heredity;2008;101:483-9.

10. Ayres JS, Schneider DS. A signaling protease required for melanization in drosophila affects resistance and tolerance of infections. PLoS Biol. 2008;6(12):2764-73.

11. Carletti G, Nervo G, Cattivelli L. Flavonoids and Melanins: A common strategy across two kingdoms. Int J Biol Sci. 2014;10(10):1159-70. 